\title{
EVALUASI ADMINISTRATIF PEMERINTAH KABUPATEN/KOTA DALAM PENERBITAN KTP ELEKRONIK BERDASARKAN UNDANG-UNDANG NOMOR 24 TAHUN 2013 TENTANG ADMINISTRASI KEPENDUDUKAN
}

\author{
Reza Amin Nugroho \\ Email : rezaaminnugroho@gmail.com \\ Mahasiswa Program Pasca Sarjana Hukum Kebijakan Publik \\ Fakultas Hukum Universitas Sebelas Maret Surakarta \\ Isharyanto \\ Email : masis_uns@yahoo.com \\ Hartriwiningsih \\ Email : hartriwi50@yahoo.com \\ Dosen Fakultas Hukum Universitas Sebelas Maret Surakarta
}

\begin{abstract}
This article examines find out the administrative evaluation and the factors affecting the effectiveness of Electronic Identity Card publication by Regency/Municipal Government based on the Law Number 24 of 2013 about Demographic Administration. This study was a normative or doctrinal research supported with secondary data including report and literature. The types of data used were primary and secondary data. Technique of collecting data used was library study. Meanwhile, data analysis was carried out using statute and historical approaches. The result showed that firstly, administrative evaluation on Regency/ Municipal Government in publishing Electronic Identity Card based on Demographic Administration Law Number 24 of 2013 about Demographic Administration had run effectively, as indicated with 96 percents of populations obliged to have Electronic Identity Card having undertaken data recording. Secondly, the factors affecting the effectiveness of Electronic Identity Card publication by R egency/Municipal Government based on Law Number 24 of 2013 about Demographic Administration showed a very closely relationship as the determinant of such the effectiveness.
\end{abstract}

Keywords : Electronic Identity Card, Demographic Document, Demographic Administration, Demographic Affairs, Population.

\begin{abstract}
Abstrak
Artikel ini mengkaji evaluasi administratif dan faktor-faktor apakah yang mempengaruhi efektifitas penerbitan KTP Elektronik oleh Pemerintah Kabupaten/Kota berdasarkan Undang-Undang Nomor 24 tahun 2013 tentang Administrasi Kependudukan. J enis penelitian dalam penulisan ini adalah normatif atau doktrinal yang didukung data sekunder berupa laporan dan bahan pustaka. J enis data yang digunakan adalah data primer dan data sekunder. Teknik pengumpulan data yang dipergunakan adalah studi pustaka. Sedangkan analisis data dilakukan dengan menggunakan pendekatan perundangundangan dan pendekatan historis. Hasil penelitian menunjukkan bahwa Pertama, evaluasi adminsitratif Pemerintah Kabupaten/Kota dalam penerbitan KTP E lektronik berdasarkan Undang-Undang Administrasi Kependudukan Nomor 24 Tahun 2013 tentang Administrasi Kependudukan berjalan efektif, terlihat dari capaian penduduk wajib KTP Elektronik yang telah melakukan perekaman data sebanyak 96 persen. Kedua, faktor-faktor yang mempengaruhi efektifitas penerbitan KTP Elektronik oleh Pemerintah Kabupaten/Kota berdasarkan Undang-Undang Nomor 24 tahun 2013 tentang Administrasi Kependudukan menunjukkan hubungan yang sangat erat sebagai faktor penentu efektifitas tersebut.
\end{abstract}

Kata Kunci : KTP Elektronik, Dokumen Kependudukan, Administrasi Kependudukan, Kependudukan, Penduduk 


\section{A. Pendahuluan}

Indonesia merupakan salah satu negara dengan jumlah penduduk yang padat. Hal ini dapat dilihat dari hasil sensus penduduk yang semakin tahun semakin meningkat. J umlah penduduk Indonesia menempati urutan pertama di negara kawasan Asia Tenggara. Menurut Badan Pusat Statistik, jumlah penduduk di Indonesia tahun 2010 adalah 237.641.326 jiwa. Penghitungan jumah penduduk dilakukan setiap 10 (sepuluh) tahun sekali, artinya Badan Pusat Statistik akan melakukan sensus penduduk pada tahun 2020 mendatang. Namun jika kita mengacu pada data yang Badan Pusat Statistik, laju pertumbuhan penduduk Indonesia sebesar 1,49 persen per tahun maka jumlah penduduk tahun 2016 adalah 258.886.460 juta jiwa (Badan PusatStatistik, http:/l sp2010.bps.go.id, diakses tangal 19 Desember 2016).

Menilik pada pengertian penduduk, pada Pasal 26 ayat (2) Undang-Undang Dasar Negara Republik Indonesia Tahun 1945 dijelaskan bahwa "Penduduk Indonesia adalah warga negara Indonesia dan warga negara asing yang bertempat tinggal di Indonesia." Penduduk yang bertempat tinggal di suatu negara harus juga taat dan patuh dengan peraturan yang berlaku di suatu negara tersebut, hal ini seperti yang diungkapkan oleh Prof. Drs. C.S.T. Kansil, SH bahwa setiap negara pasti mempunyai penduduk, karena penduduk mempunyai pengertian yaitu orang yang bertempattinggal dalam wilayah suatu negara dan tunduk pada kekuasaan negara (Kansil, 2002 : 45).

Kependudukan merupakan basis utama dan fokus dari segala persoalan pembangunan. Hampir kegiatan pembangunan baik yang bersifat sektoral maupun lintas sektor terarah dan terkait dengan penduduk, atau dengan kata lain penduduk harus menjadi subyek sekaligus objek pembangunan. Kualitas penduduk yang baik akan melahirkan sumber daya manusia (SDM) yang baik pula. Oleh sebab itu kependudukan saat ini telah menjadi perhatian khusus di Indonesia seiring dengan meningkatnya kompleksitas dan dinamika kependudukan global. Salah satu dokumen kependudukan yang penitng adalah KTP Elektronik. Penerbitan KTP elektronik ini merupakan salah satu bentuk pelayanan pemerintah yang harus dilaksanakan, karena dari pelayanan tersebut pemerintah akan memperoleh kemudahan dalam mengatur bentuk-bentuk pelayanan publik misalnya bidang pendidikan, kesehatan, jaminan kesejahteraan sosial dan lain sebagainya.

Penyelenggaraan pelayanan publik saat ini menjadi isu kebijakan yang aktual di masyarakat seiring dengan implementasi kebijakan desentralisasi dan otonomi daerah di Indonesia. Kebijakan otonomi daerah berdasarkan UndangUndang Nomor 23 tahun 2014 telah membawa angin baru dan optimisme daerah dalam mengatur dan mengurus kepentingan masyarakatnya serta nuansa baru dalam hubungan antara pusat dan daerah. Masyarakat di daerah yang selama ini lebih banyak dalam posisi dimarginalkan, selanjutnya diberi kesempatan untuk mendapatkan pengakuan dan penghargaan terhadap hak,aspirasi, dan kepentinganya (Syaukani, 2007 : 102).

Oleh karena itu pemerintah mengeluarkan kebijakan Undang-Undang Undang-Undang Nomor 24 Tahun 2013 tentang Administrasi Kependudukan., Perubahan Atas Undang-Undang Nomor 23 Tahun 2006 tentang Administrasi Kependudukan, yang diharapkan akan dapat memberikan manfaat antara lain, untuk merancang program Pembangunan Daerah di bidang pendidikan, kesehatan dan pelayanan-pelayanan lain yang membutuhkan data kependudukan yang akurat, untuk keperluan perencanaan dalam penyediaan fasilitas-fasilitas sosial ekonomi, seperti penyediaan rumah sakit, puskesmas, pasar, fasilitas pendidikan dan lain sebagainya (Faturochman, 2004:4-5).

Undang-Undang Nomor 24 Tahun 2013 tentang Administrasi Kependudukan, Perubahan Atas Undang-Undang Nomor 23 Tahun 2006 tentang Administrasi Kependudukan, Peraturan Pemerintah Nomor 102 Tahun 2012 perubahan atas Peraturan Pemerintah Nomor 37 Tahun 2007 tentang Pelaksanaan Undang-Undang Nomor 23 tahun 2006 menjamin hak seorang/kelompok penganut Penghayat Kepercayaan Terhadap Tuhan Yang Maha Esa untuk mendapatkan hakhak administrasi kependudukan dan melaksanakan kewajiban administrasi kependudukan yang di dalamnya merupakan dokumen kependudukan yang salah satunya merupakan KTP. Dalam Undang-Undang tersebut telah jelas diatur bahwa yang berkewajiban, bertanggung jawab dan berwenang melaksanakan penyelenggaraan urusan administrasi kependudukan di tingkat daerah adalah pemerintah daerah yang dilakukan oleh Bupati atau Walikota.

Berdasarkan fenomena di atas, pembahasan pada tulisan ini difokuskan pada evaluasi administratif terhadap penerbitan KTP Elektronik 
oleh Pemerintah Kabupaten/Kota berdasarkan Undang-Undang Nomor Nomor 24 Tahun 2013 tentang Administrasi Kependudukan serta faktorfaktor yang dapat mempengaruhi efektivitas penerbitan KTP Elektronik tersebut.

\section{B Metode Penelitian}

J enis penelitian ini adalah hukum normatif (Soerdjono Sukanto, 1985:42). Menurut Soerjono Soekanto bahwa penelitian hukum yang dilakukan dengan cara meneliti bahan pustaka atau sekunder belaka, dapat dinamakan penelitian hukum normatif atau penelitian hukum kepustakaan. (Sutrisno Hadi, 1989:4). Dilihat dari sifatnya penelitian ini termasuk penelitian diagnostik (J ohny Ibrahim, 2006:57).

Data yang dikumpulkan terutama merupakan data pokok yaitu data yang disempurnakan dengan penggunaan data pelengkap. Penelitian ini menggunakan data sekunder berupa bahanbahan hukum. Data sekunder, adalah data yang berasal dari data-data yang sudah tersedia misalnya, dokumen resmi, surat perjanjian atau buku-buku. Data Sekunder dapat berupa bahan hukum P rimer, S ekunder maupun Tertier (S etiono, 2002:6).

Bahan hukum yang dipergunakan adalah bahan hukum primer, bahan hukum sekunder, dan bahan hukum tersier. Teknik pengumpulan bahan hukum yang digunakan dalam penelitian ini adalah studi pustaka (P eter Mahmud Marzuki, 2014:181), sedangkan teknik analisis data menurut J ohny Ibrahim (2006:305) dalam penelitian ini menggunakan pendekatan perundang-undangan (statue approach) dan pedekatan historis (historical approach).

\section{Hasil Penelitian dan Pembahasan}

Dalam kehidupan modern seperti sekarang ini dengan segala kegiatan pemerintahan tidak dapat lepas dari apa yang disebut sebagai kebijakan publik. Kebijakan-kebijakan tersebut dapat ditemukan dalam bidang antara lain kesejahteraan sosial (social welfare), di bidang kesehatan, perumahan rakyat, pertanian, pembangunan ekonomi, hubungan luar negeri, pendidikan nasional dan lain sebagainya.

Harold D. Laswell memberikan definisi kebijakan publik sebagai berikut:

1) Kebijakan Publik adalah suatu program pencapaian tujuan, nilai-nilai dan praktekpraktek yang terarah.
2) Kebijakan publik adalah apa saja yang dilakukan maupun tidak dilakukan oleh pemerintah (S etiono, $2004: 4$ )

Menurut Michael Howlett (1998 : 26) dalam Policy Studies Journal, menyebutkan Formulasi Kebijakan P ublik adalah "The publik policy formulation is the most initial step in overall publik policy process. For that reason, what happens to this phase will highly determine whether or not the publik policy made is successful in the future.

Dapatditerjemahkan antara lain bahwa langkah yang paling awal dalam proses kebijakan publik secara keseluruhan. Oleh karenanya apa yang terjadi pada fase ini akan sangat menentukan berhasil tidaknya kebijakan publik yang dibuat itu pada masa yang akan datang.

Menurut Pendapat Thomas Biekland (1998 : 26) dalam Policy Studies J ournal, melihat hubungan hukum dan kebijakan publik yaitu :

"The most fundamental way to see the relationship between law and publik policy is the understanding that basically, publik policy should generally legalized into law form, basically, a law is the result of publik policy".

Apabila diartikan adalah yang paling mendasar untuk melihat hubungan antara hukum dan kebijakan publik adalah pemahaman bahwa pada dasarnya, kebijakan publik umumnya harus dilegalisasikan dalam bentuk hukum, pada dasarnya sebuah hukum adalah hasil dari kebijakan publik.

Di Indonesia apabila seorang warga negara tidak mematuhi peraturan hukum yang ada maka akan menemui kesulitan dalam memperoleh hak nya sebagai warga negara. Terlebih jika suatu kebijakan hukum diatur dalam Undang-Undang yang merupakan dasar hukum tertinggi di negara ini, maka merupakan suatu kewajiban bagi seluruh warga negara untuk mematuhi aturan yang berlaku demi terwujudnya kesejahteraan bersama. Dalam artikel ini, membahas tentang kebijakan pemerintah dalam hal administrasi kependudukan yang merupakan hal penting dalam kehidupan berbangsa dan bernegara sehingga dapat memberikan keabsahan, perlindungan hak dan kepastian hukum atas dokumen kependudukan.. Dalam hal ini pemerintah mengeluarkan kebijakan 
Undang-Undang Nomor 24 Tahun 2013 tentang Administrasi Kependudukan, yang diharapkan akan dapatmemberikan manfaat untuk merancang program pembangunan di semua bidang.

Berlakunya Undang-Undang Nomor 24 tahun 2013 tentang Administrasi Kependudukan menjadi dasar diterbitkannya peraturan lain tentang KTP Elektronik, seperti Peraturan Presiden, Peraturan Menteri, Surat Edaran Menteri kepada jajaran Instansi Pelaksana. Peraturan lain yang mendukung pelaksanaan KTP Elektronik merupakan upaya Pemerintah guna mempermudah jajaran Instansi Pelaksana dalam melaksanakan penerbitan KTP Elektronik.

Dari penerbitan peraturan perundangundangan tersebut, tercipta suatu pedoman kerja bagi Instansi Pelaksana penerbitan KTP Elektronik dalam hal ini Pemerintah Kabupaten/ Kota yang mendelegasikan wewenangnya kepada Dinas Kependudukan dan Pencatatan Sipil di masing-masing wilayah. Berdasarkan hal tersebut di atas perlu melihat efektifitas peraturan perundang-undangan dengan melakukan evaluasi adminsitratif Pemerintah Kabupaten/Kota.

Soerjono Soekanto (2002:15) menyatakan bahwa untuk dapat terlaksananya suatu peraturan perundang-undangan secara efektif, itu dipengaruhi oleh beberapa faktor yaitu sebagai berikut:

a. Faktor hukumnya sendiri;

b. Faktor penegak hukum, yakni pihak-pihak yang membentuk maupun menerapkan hukum;

c. Faktor sarana atau pasilitas yang mendukung penegak hukum;

d. Faktor masyarakat, yakni lingkungan dimana hukum tersebut berlaku atau diterapkan;

e. Faktor kebudayaan, yakni sebagai hasil karya, cipta dan rasa yang didasarkan pada karsa manusia di dalam pergaulan hidup.

Kelima faktor tersebut kemudian penulis kaji dengan menggunakan Teori Sistem Hukum dari Lawrence M. Friedman. Teori sistem hukum dari Lawrence M. Friedman (1969:16) menyatakan bahwa sebagai suatu sistem hukum dari sistem kemasyarakatan, maka hukum mencakup tiga komponen yaitu:

a. Legal Substance (Substansi Hukum) merupakan aturan-aturan, norma-norma dan pola prilaku nyata manusia yang berada dalam sistem itu termasuk produk yang dihasilkan oleh orang yang berada di dalam sistem hukum itu, mencakup keputusan yang mereka keluarkan atau aturan baru yang mereka susun.

b. Legal Structure (Struktur Hukum) merupakan kerangka, bagian yang tetap bertahan, bagian yang memberikan semacam bentuk dan batasan terhadap keseluruhan instansi-instansi penegak hukum. Di Indonesia yang merupakan struktur dari sistem hukum antara lain institusi atau penegak hukum seperti advokat, polisi, jaksa dan hakim.

c. Legal Culture (Budaya Hukum) merupakan suasana pikiran sistem dan kekuatan sosial yang menentukan bagaimana hukum itu digunakan, dihindari atau disalahgunakan oleh masyarakat.

Dari ketiga komponen-komponen dalam sistem yang saling mempengaruhi satu sama lainnya tersebut, maka dapat dikaji bagaimana bekerjanya hukum dalam praktek seharihari. Dengan demikian teori sistem hukum ini menganalisa masalah-masalah terhadap penerapan subastansi hukum, struktur hukum dan budaya hukum yang didalamnya meliputi hukum/ undang-undang, penegak hukum, sarana dan prasarana, kebudayaan dan masyarakat.

1. Evaluasi Administratif Pemerintah Kabupaten/Kota dalam Penerbitan KTP Elektronik Berdasarkan Undang-Undang Nomor 24 tahun 2013 tentang Administrasi Kependudukan.

\section{a) Penerapan Substansi Hukum}

Produk hukum dalam penelitian ini adalah Undang-Undang Nomor 24 tahun 2013 tentang Administrasi Kependudukan, yang didukung oleh Pe. GG. Howard dan RS Summers menyatakan bahwa : "faktor-faktor yang mempengaruhi keefektifan hukum adalah undang-undang/peraturan daerah yang mengaturnya harus dirancang dengan baik (perancangan undang-undang/ peraturan daerah dan mereka yang bekerja sebagai pelaksana hukum harus memusatkan tugasnya dengan baik pula" (GG. Howard dan RS Summers, 1965:46-47). Pendapat tersebut sejalan dengan teori efektivitas milik Soerjono Soekanto () yang menyatakan salah satu faktor yang mempengaruhi efektivitas penegakan hukum adalah hukum/ 
undang-undang.

Melihat isi ketentuan/pengaturan mengenai KTP Elektronik sebagaimana yang tertuang dalam Undang-Undang Nomor 24 tahun 2013 perubahan atas Undang-Undang Nomor 23 tahun 2006 tentang Administrasi Kependudukan dapat dikatakan bahwa Undang-Undang tersebut sudah baik. Hal-hal yang diatur dalam Undang-Undang tersebut dirumuskan secara jelas, sistematis dan mudah dimengerti oleh semua pihak sehingga setiap isi ketentuan mengenai penerbitan KTP Elektronik tidak menimbulkan penafsiran yang berbeda-beda bagi setiap orang yang membacanya baik itu pelaksana/pegawai yang bertugas menangani penerbitan KTP Elektronik maupun masyarakat umum.

$\mathrm{Hal}$ tersebut terbukti dengan diundangkannya Undang-Undang Nomor 24 tahun 2013 tentang Administrasi Kependudukan telah membantu meningkatkan jumlah penduduk yang memiliki KTP Elektronik. Seperti berita yang banyak dirilis pada website resmi milik Kementerian Dalam Negeri, Kementerian yang bertanggungjawab atas keberhasilan penerbitan KTP Elektronik di tingkat pusat. Salah satu ungkapan yang disampaikan oleh Prof. Dr. Zudan Arif Fakrulloh, S.H, M.Si selaku Dirjen Kependudukan dan Pencatatan Sipil Kementerian Dalam Negeri pada awal Desember tahun 2016 yang memastikan bahwa saat ini hanya tersisa 4 persen atau 7,6 juta penduduk yang memiliki KTP E lektronik (Anonim, http://www.kemendagri.go.id/ news/2016/12/02/perekaman-ktp-elsecara nasional-tembus-96-persen, diakses 15 Desember 2016). Ini artinya penerbitan KTP Elektronik dalam skala nasional hingga bulan Desember 2016 telah menembus angka 96 persen.

Data tersebut telah diungkapkan Tjahjo Kumolo, bahwa data penduduk Indonesia pada 31 J uni 2016 mencapai 257.912.349 jiwa, sedangkan jumlah data penduduk wajib KTP per 31 Desember 2015 sejumlah 182.588.494 jiwa. "Untuk penduduk Indonesia yang sudah melakukan perekaman data untuk kebutuhan E-KTP per 31 Agustus 2016 kemarin, baru 162.047.403 jiwa. Artinya, masih ada sekitar 20.541.091 jiwa yang belum merekam data," terang Tjahjo kepada Tribun J ateng (Deni Setiawan, http://jateng.tribunnews.com/2016/09/01/ data-terkini-jumlah-penduduk-indonesia2579-juta-yang-wajib-ktp-1825-jutam diakses tanggal 18 Desember 2016) .

Efektifitas lain dari substansi hukum yang terkandung dalam Undang-Undang Nomor 24 tahun 2013 adalah adanya petunjuk teknis bagi penyelenggara, Instansi Pelaksana maupun masyarakat dalam mensukseskan penerbitan KTP Elektronik. Sehingga tugas pokok dan fungsi masing-masing elemen secara eksplisit tercantum dengan jelas. Selain itu diberlakukan pula sanksi administratif dan ketentuan pidana bagi pelanggar hukum, tidak hanya denda dan pidana bagi masyarakat yang tertangkap tangan menggandakan / memalsukan / menambah / mengurangi isi elemen data pada dokumen kependudukan dalam hal ini KTP Elektronik namun juga kepada pejabat/aparat/pelaksana yang terlibat penerbitan KTP Elektronik. Tidak tanggung-tanggung, denda yang disanksikan jika melakukan pelanggaran mengenai dokumen kependudukan adalah mencapai angka Rp 1.000.000.000 ( satu milyar rupiah). Keseriusan pemerintah menertibkan para pejabat yang bersangkutan dalam penyelenggaraan penerbitan KTP Elektronik adalah dengan memberikan sanksi pidana yang sama dengan pelanggaran yang dilakukan penduduk ditambah $1 / 3$ (sepertiga) hukuman.

Aturan yang diundangkan dalam Undang-Undang Nomor 24 tahun 2014 tentang Administrasi Kependudukan telah mencakup wewenang Pemerintah Kabupaten/ Kota dalam menyelenggarakan Administrasi Kependudukan, termasuk Instansi Pelaksana dalam hal ini Dinas Kependudukan dan Pencatatan Sipil di Kota/Kabupaten. Sanksi administratif dan ketentuan pidana juga telah tertuang sehingga menimbulkan efek jera kepada seluruh elemen, baik penyelenggara, 
pelaksana dan wajib KTP itu sendiri. Berdasarkan penjelasan di atas substansi hukum Undang-Undang Nomor 24 tahun 2013 tentang Administrasi Kependudukan dinilai baik dan efektif untuk penduduk dalam penerbitan KTP Elektronik.

\section{b) Penerapan Struktur Hukum}

Pada pasal 7 Undang-Undang Nomor 24 Tahun 2013 tentang Administrasi Kependudukan telah dijelaskan bahwa yang memiliki wewenang dalam melakukan penyelenggaraan Administrasi Kependudukan adalah Pemerintah Kabupaten/Kota dalam hal ini Bupati/Walikota. Penjelasan atas pelaksanaan Undang-Undang Nomor 24 tahun 2013 perubahan atas UndangUndang tahun 2006 tentang Administrasi Kependudukan tertuang dalam Peraturan Pemerintah Nomor 37 tahun 2007. Lebih lanjut dijelaskan bahwa wewenang Bupati/Walikota dalam pelaksanaan Administrasi Kependudukan adalah melakukan koordinasi dan sosialisasi antarinstansi vertikal dan lembaga pemerintah non departemen, kerjasama dengan organisasi masyarakat dan perguruan tinggi, sosialisasi iklan layanan masyarakat melalui media cetak dan elektronik, dan komunikasi, informasi dan edukasi kepada seluruh lapisan masyarakat.

Sesuai penjelasan pasal 27 dalam Peraturan Pemerintah Nomor 37 tahun 2007 bahwa, "Dalam menyelenggarakan urusan Administrasi Kependudukan di Kabupaten/Kota, dibentuk Dinas Kependudukan dan Pencatatan Sipil yang diatur dalam Peraturan Daerah." Sebagai Instansi Pelaksana Dinas Kependudukan dan Pencatatan Sipil.

Beberapa upaya ditempuh Pemerintah Kabupaten/Kota bersama jajarannya di Pemerintah Daerah seperti yang dilakukan Walikota Surabaya, Tri $\mathrm{R}$ ismaharini yang memerintahkan anak buah nya untu langsung ketuk pintu, bahkan dirinya memerintahkan jajaran staf Dinas Kependudukan dan Pencatatan Sipil untuk mengendarai motor melakukan jemput bola ke rumah warga (Anonim, http://www.kemendagri. go.id/news/2016/08/31/mendagri-puiirisma-yang-perintahkan-anak-buah- door-to-door-layani-e-ktp, diakses tanggal 18 Desember 2016). Kendala yang dihadapi ketika melakukan metode ini adalah ketika pemilik rumah tidak berada di tempat atau sedang bekerja, sehingga diutamakan untuk menjangkau penduduk yang berusia tua, jompo, mengalami sakitkeras maupun penduduk berkebutuhan khusus. Sedangkan penduduk yang berada di kota besar dalam usia produktif dihimbau untuk aktif merekam data KTP Elektronik di kantor Dinas Kependudukan dan Pencatatan Sipil atau UPTD Kecamatan setempat.

Selain upaya jemput bola atau door to door ke rumah penduduk, kreatifitas aparat lainnya adalah dengan mendatangi lokasi keramaian seperti acara Car Free Day di Tenggarong Kabupaten Kutai Kartanegara. Dalam kesempatan tersebut, Kepala Dinas Kependudukan dan Pencatatan Sipil Kabupaten Kutai Kartanegara mengungkapkan bahwa antusiasme masyarakat dalam pelayanan KTP Elektronik di CFD Tenggarong sangat tinggi, pelayanan dibuka pagi hari hingga berakhirnya CFD terkumpul 150 ( seratus lima puluh ) penduduk merekam KTP Elektronik (Anonim, http://www. kemendagri.go.id/news/2016/11/07/ perekaman-ktp-el-di-tenggarong-carfree-day, diakses tanggal 20 Desember 2016).

Selain Kabupaten KutaiKartanegara, pelayanan KTP Elektronik di lokasi Car Free Day adalah Kota Surakarta, Kabupaten Malang, Kota Bogor, Kota Semarang, Kabupaten Bondowoso, Kabupaten Karanganyar, Kabupaten Ponorogo, Kota Surabaya dan masih banyak Kota/Kabupaten lainnya. Selain membuka pelayanan di acara Car Free Day, Dinas Kependudukan dan Pencatatan Sipil memanfaatkan waktu di sela-sela Kegiatan Belajar Mengajar di SMA/SMK untuk melakukan perekaman KTP Elektronik.

Perekeman KTP Elektronik tidak dapat tersimpan menjadi database yang baik jika tidak ditunjang dengan peralatan yang memadai. Seperti yang telah dijelaskan dalam Pedoman Teknis Pelaksanaan Kegiatan Pembantuan 
Administrasi Kependudukan di Kabupaten/Kota tahun 2014 yang diterbitkan Dirjen Kependudukan dan Pencatatan Sipil Kementerian Dalam Negeri menjelaskan secara rinci perangkat lunak dan perangkat keras yang dipergunakan dalam perekaman KTP Elektronik di setiap Kabupaten/ Kota. Sebagian besar perangkat tersebut dipersiapkan khusus guna menunjang perekaman KTP Elektronik.

Penerbitan KTP Elektronik telah memiliki alokasi anggaran khusus, mulai dari penerbitan Nomor Induk Kependudukan (NIK) dan penerapan KTP Elektronik di Kabupaten/Kota yang dibebankan pada Anggaran Pendapatan dan Belanja Negara (APBN) melalui Kementerian Dalam Negeri sebesar 6,68 triliun rupiah. Dana tersebut dilokasikan secara bertahap sejak tahun 2010 untuk disalurkan kepada Pemerintah Kabupaten/Kota se-Indonesia. Hal tersebutsejalan dengan pasal $87 \mathrm{~A}$ dan 87 B Undang-Undang Nomor 24 tahun 2013 yang menjelaskan tentang pendanaan kegiatan Administrasi Kependudukan baik di provinsi atau kabupaten/kota dianggarkan dalam APBN perubahan tahun anggaram 2014.

Secara struktur hukum, Pemerintah Kabupaten/Kota telah menyelenggarakan urusan administrasi kependudukan khususnya penerbitan KTP Elektronik dengan baik sesuai aturan perundangundangan. Hal tersebut juga didukung dengan sarana dan prasarana yang meliputi fasilitasi perangkat lunak dan keras, sumber keuangan, dan organisasi yang baik.

\section{c) Penerapan Budaya Hukum}

Kultur hukum atau budaya hukum (Legal Culture) adalah suasana pikiran sosial yang menentukan bagaimana hukum itu digunakan, dihindari, atau disalahgunakan. Menurut Soerjono Soekanto efektivitas penegakan hukum salah satunya dipengaruhi oleh kebudayaan dan masyarakat. Sedangkan dalam kaitan dengan budaya hukum Lawrence M. F riedman membedakannya menjadi dua bagian, yaitu:

(1) Budaya hukum eksternal (external legal culture)
(2) Budaya hukum internal (internal legal culture)

Budaya hukum ekternal adalah budaya hukum dari warga masyarakat secara umum sedangkan budaya hukum internal adalah budaya hukum dari kelompok orang-orang yang mempunyai profesi di bidang hukum seperti hakim, birokrat dan lain-lainnya. Menurut Friedman, kekuatan-kekuatan sosial secara terus menerus mempengaruhi sistem hukum, kadang-kadang ia merusak, memperbaharui, memperkuat, atau memilih untuk lebih menampilkan segi-segi tertentu. Dalam melihat hukum sebagai suatu sistem yang terdiri dari unsur-unsur sebagaimana yang dikemukakan oleh Lawrence $M$. Firedman yaitu struktur, substansi dan kultur atau budaya, dimana unsur-unsur yang satu dengan yang lainnya saling mempengaruhi dalam bekerjanya hukum pada kehidupan sehari-hari. Perubahan-perubahan sosial yang serba cepat dan perkembangan yang tidak sama dalam kebudayaan, mengakibatkan ketidakmampuan banyak individu untuk menyesuaikan diri, mengakibatkan timbulnya disharmoni, konflik-konflik eksternal dan internal, juga terjadinya disorganisasi dalam masyarakat dalam diri pribadi.

Penduduk di Indonesia memiliki kesadaran melakukan perekaman KTP Elektronik karena banyaknya manfaat KTP E lektronik, seperti sebagai persyaratan utama pembuatan paspor, SIM, urusan perbankan, pengajuan pernikahan, pembelian barang berharga (mobil, motor, rumah, tanah, dll), pembelian tiket (pesawat, kereta api, dan kapal), sebagai alat memperoleh fasilitas kesehatan, seperti BPJ S Kesehatan, atau asuransi kesehatan lainnya. Sedangkan fasilitas ekonomi nya adalah sebagai alat untuk mendapatkan Kartu Indonesia P intar.

KTP Elektronik memaksa seseorang untuk wajib memilikinya karena manfaat yang mempermudah urusan administrasi kependudukan masing-masing. Sehingga kesadaran untuk melakukan perekaman KTP Elektronik muncul dari sebagian besar penduduk. Untuk sebagian lainnya tentu terdapat beberapa kendala yang menjadikan alasan penduduk belum melakukan perekaman KTP Elektronik.

Kegunaan KTP Elektronik untuk urusan kependudukan lainnya dengan menggunakan Nomor Induk Kependudukan sebagai dasar 
penerbitan paspor, surat izin mengemudi, nomor pokok wajib pajak, polis asuransi, sertifikat hak tanah, dan penerbitan doukmen identitas lainnya, seperti yang tercantum pada Undang-Undang Nomor 24 tahun 2013 tentang Administrasi Kependudukan.

2. Faktor-Faktor Yang Mempengaruhi Evaluasi Administratif Pemerintah Kabupaten/Kota dalam Penerbitan KTP Elektronik Berdasarkan Undang-Undang Nomor 24 tahun 2013 tentang Administrasi Kependudukan

Faktor-faktor yang mempengaruhi efektivitas penerbitan KTP Elektronik oleh Pemerintah Kabupaten/Kota berasarkan Undang-Undang Nomor 24 Tahun 2013 Tentang Administrasi Kependudukan ditinjau dari 3 (tiga) komponen sistem hukum menurut Lawrence M. Friedman adalah sebagai berikut :

\section{a) Penerapan Substansi Hukum}

Sebelum diundangkannya UndangUndang mengenai Administrasi Kependudukan dalam hal ini penerbitan KTP E lektronik, masih terdapatpenduduk yang belum memiliki KTP Elektronik. J umlah wajib KTP per 31 Desember 2015 adalah 182.588.494 jiwa, sedangkan penduduk yang telah merekam data KTP Elektronik sebanyak 162.047.403 jiwa telah merekam data KTP Elektronik pada pertengahan tahun 2016 (Deni S etiawan, http://jateng tribunnews. com/2016/09/01/data-terkini-jumlah penduduk-indonesia-2579-juta-vangwaiib-ktp-1825-jutam diakses tanggal 18 Desember 2016). Ini berarti masih ada 20.541.091 jiwa yang belum memiliki KTP Elektronik. Angka yang cukup tinggi untuk dokumen kependudukan yang sangat penting. Ketika jumlah ini dirilis, Pemerintah Kabupaten/Kota sudah berupaya dalam mencapai target penduduk yang merekam KTP E lektronik. Sehingga dapat disimpulkan bahwa jumlah penduduk yang belum memiliki KTP E lektronik sebelum diundangkannya Undang-Undang Nomor 24 tahun 2013 lebih tinggi.

Salah satu penentu berhasilnya pencapaian target kepemilikan KTP Elektronik per Desember 2016 hingga mencapai angka 96 persen adalah penetapan ketentuan hukum Undang-
Undang Nomor 24 tahun 2013 tentang Administrasi Kependudukan terbaru, salah satu didalamnya memuat pedoman kerja Dinas Kependudukan dan Pencatatan Sipil dalam urusan kependudukan yang selanjutnya diatur lebih jelas dalam Peraturan Pemerintah. Untuk mencapai efektifitas penerbitan KTP Elektronik dilakukan beberapa strategi, diantaranya :

(1) Reformasi Kebijakan

(2) Reformasi Administrasi

Reformasi kebijakan guna meningkatkan efektivitas kepemilikan KTP Elektronik adalah perubahan Undang-Undang Nomor 23 tahun 2006 menjadi Undang-Undang Nomor 24 tahun 2013. Penyempurnaan peraturan yang terkandung lebih merujuk pada KTP Elektronik yang sebelumnya hanyak KTP saja. Selain petunjuk teknis bagi pemerintah kabupaten/kota, terdapat sisipan antara pasal 95 dan 96 Undang-Undang Nomor 24 tahun 2013. Pasal tersebut adalah Pasal 95B yang khusus mengatur sanksi pidana bagi pejabat dan petugas mulai dari jajaran desa/kelurahan, kecamatan, UPTD Instansi pelaksana (dalam hal ini UPT Dinas Kependudukan dan Pencatatan Sipil) dan Instansi Pelaksana (Dinas Kependudukan dan Pencatatan Sipil tingkat Kabupaten/Kota). Dalam pasal tersebut dijelaskan larangan bagi instansi pelaksana dan jajarannya untuk memfasilitasi/melakukan pungutan liar kepada penduduk dalam pengurusan dokumen kependudukan, jika aparat instansi pelaksana masih melanggarakan dikenai hukuman 6 (enam) tahun dan/ atau denda maksimal Rp 75.000.000,-.

Selain reformasi kebijakan yang mengandung hukuman bagi aparatur penyelenggara dalam Peraturan Menteri Dalam Negeri Nomor 65 tahun 2012 tentang Pemberian Penghargaan dalam Pelaksanaan Pelayananan KTP Elektronik secara massal maka dapat diketahui bahwa Pemerintah memberikan hadiah kepada aparatur di tingkat kabupaten/kota. Lebih lanjut dijelaskan penghargaan tersebut diberikan kepada kabupaten/kota yang masuk dalam 10 (sepuluh) tertinggi hasil pelayanan 
KTP Elektronik secara massal di 197 kabupaten/kota untuk tahun 2011 dan 300 kabupaten/kota di tahun 2012. Adapun bentuk penghargaan yang diberikan adalah piagam penghargaan dan mobil dan/atau sepeda motor.

Reformasi kebijakan lain yang diambil pemerintah pusat untuk dilaksanakan oleh Pemerintah Kabupaten/Kota dalam rangka meningkatkan kepemilikan KTP Elektronik adalah mengeluarkan Surat Edaran Menteri Dalam Negeri Nomor 471/1768/SJ tanggal 12 Mei 2016 tentang Percepatan Penerbitan KTP Elektronik dan Akta Kelahiran. Dalam SuratE daran tersebut menyebutkan bahwa dengan dilatarbelakanginya hak kepemilikan KTP Elektronik oleh penduduk Indonesia dan cakupan perekaman KTP Elektronik yang baru mencapai angka 86 persen, maka dihimbau kepada Dinas Kependudukan dan Pencatatan Sipil melalui Bupati/ Walikota untuk melakukan percepatan pelayanan KTP Elektronik dengan menghapus syaratpembayaran P BB dan surat pengantar mulai $R T, R W$, Kelurahan hingga Kecamatan.

Jika merujuk pada Reformasi Administrasi adalah memperbaiki sistem kinerja Dinas Kependudukan dan Pencatatan Sipil sekaligus UPT sebagai fungsi tugas pembantuan. Pelayanan publik sebelumnya yang hanya menerbitkan KTP biasa tanpa melakukan perekaman data seperti rekam sidik jari, rekam iris, foto di tempat, dan penggunaan Sistem Informasi Administrasi Kependudukan (SIAK) sehingga menuntut aparatur pelaksana untuk menguasai perangkat-perangkat pendukungnya. Himbauan Surat E daran tersebut aparatur pelaksana diharapkan mampu meningkatkan pelayanan publik dengan meningkatkan penguasaan pemakaian alat baca KTP Elektronik atau card reader.

\section{b) Penerapan Substansi Hukum}

Penerapan struktur hukum menjadi salah satu faktor yang mempengaruhi berhasil tidaknya suatu kebijakan hukum. Pemerintah kabupaten/kota sebagai pelaksana kebijakan mengenai penerbitan KTP Elektronik dituntut memiliki pemahaman yang cukup tinggi dan respon yang positif. Pemahaman akan kebijakan dapat terlihat dari semangat kerja dan tanggungjawab yang terlihat dalam penyelenggaraan urusan kependudukan beberapa tahun terakhir.

Aparatur juga melaksanakan pelayanan yang inovasi dan kreatif seperti melakukan jemput bola perekaman KTP Elektronik di lokasi strategis (sekolah, Car Free Day, pusat keramaian lainnya), melakukan upaya door to door di rumah penduduk, rumah sakit dan panti jompo, memperbaiki sistem antrian agar penduduk tidak terlalu lama menunggu di lokasi perekaman KTP E lektronik.

Dalam hal penyediaan dan penyerahan blangko dokumen kependudukan dan formulir sempat mengalami kekosongan, hal tersebut mendapat tanggapan dari Dirjen Kependudukan dan Pencatatan Sipil, Dr. Zudan menyatakan bahwa tidak ada perusahaan yang memenuhi kelayakan administratif dan uji teknis untuk memenuhi 8 (delapan) juta keping blangko KTP Elektronik (Anonim, http:/l www.beritasatu.com/hukum/399481blangko-ektp-gagal-lelang.html, diakses tanggal 20 Desember 2016).

Dinas Kependudukan danPencatatan Sipil Kabupaten/Kota menebitkan Surat Pengganti Blangko KTP Elektronik. Seperti Dinas Kependudukan dan Pencatatan Sipil Kabupaten Pekalongan telah menerbitkan sebanyak 1.029 surat keterangan pengganti KTP elektronik yang memiliki fungsi sama dengan KTP Elektronik (Anonim, http://www. radarpekalongan.com/54596/ribuansurat-pengganti-ktp-el-diterbitkan-sejakblangko-habis, diakses 19 Desember 2016).

Salah satu keberhasilan pencapaian jumlah pemilik KTP Elektronik di Indonesia ditunjang oleh perangkat pendukung KTP Elektronik seperti yang telah dijelaskan pada penjelasan sebelumnya. Tentu tidak semua aparatur di jajaran instansi pelaksana mampu mengoperasikan peralatan pendukung KTP Elektronik karena faktor-faktor yang mempengaruhi seperti : kurang menguasai pengoperasian komputer, tidak memiliki keahlian di bidang IT, 
dan faktor usia. kecenderungan tidak menguasai pengoperasian komputer pada aparatur yang telah menginjak usia tua adalah karena kebiasaan menggunakan peralatan manual non elektronik.

\section{c) Penerapan Budaya Hukum}

Meskipun peraturan telah terbentuk, aparat penegak hukum telah bekerja secara maksimal, namun selalu ada kendala walaupun jumlahnya minoritas. Penduduk Indonesia yang wajib KTP Elektronik memiliki latarbelakang yang heterogen, misalnya dari faktor usia. Seorang yang sudah tua menganggap bahwa dirinya tidak membutuhkan KTP Elektronik. Seperti yang ditemukan aparatur di jajaran Dinas Kependudukan dan Pencatatan Sipil Kota Yogayakarta menemui warga jompo yang bersifat acuh karena merasa tidak memerlukan KTP E lektronik sebab merasa sudah tidak membutuhkan dokumen kependudukan lainnya (Anonim, http://www.kemendagri. go.id/news/2016/09/28/dinas-dukcapilgunung-kidul-door-to-door-e-ktp-sampaike-tempat-tidur, diakses 17 Desember 2016).

Faktor hambatan lainnya adalah pekerjaan, yang menuntut masyarakat harus berada di kantor selama jam kerja dan tidak dapat meninggalkan pekerjaannya untuk urusan Administrasi Kependudukan atau karena sibuk bekerja tidak dapat meluangkan waktunya. Hal ini menjadi perhatian khusus aparatur untuk membuka pelayanan KTP Elektronik di hari libur. Faktor geografis Indonesia yang terdiri dari beberapa pulau dan masih banyak daerah terpencil membuat masyarakat di lokasi tersebut enggan menuju Kantor pelayanan untuk merekam KTP Elektronik. Sehingga diperlukan upaya jemput bola aparatur pemerintah daerah.

Penggalakan percepatan pelayanan KTP Elektronik oleh Pemerintah Pusat kepada Pemerintah Kabupaten/Kota tentu tidak tanpa alasan. Beberapa dampak penerapan KTP Elektronik secara nasional adalah terciptanya keamanan negara, sebagai alat demokrasi (pemilu dan pilkada), meningkatkan citra/eksistensi negara, memperjelas status kependudukan seseorang, mempermudah negara melakukan perencanaan pembangunan, mempermudah akses pelayanan publik (kepolisian, perbankan, pajak, bisnis, dan lain-lain), menunjukkan data statistik yang akurat, mempermudah penduduk berpergian, menekan angka kejahatan terorisme baik domestik maupun internasional, meminimalisir adanya pekerja ilegal/imigran gelap, dan menekan angka penyalahgunaan dokumen penduduk.

Jika seluruh penduduk wajib KTP Elektronik telah melaksanakan kewajibannya sebagai penduduk yang tertib hukum dengan melakukan perekaman KTP Elektronik dan Pemerintah Kabupaten/Kota mampu melakukan penerbitan KTP Elektronik kepada seluruh wajib KTP Elektronik, maka diberlakukannya UndangUndang Nomor 24 tahun 2013 tentang Administrasi Kependudukan dianggap berjalan dengan efektif.

\section{Simpulan}

Evaluasi Administratif P emerintah Kabupaten/ Kota dalam Penerbitan KTP Elektronik Berdasarkan Undang-Undang Nomor 24 tahun 2013 tentang Administrasi Kependudukan telah menunjukkan bahwa kebijakan tersebut telah berjalan efektif. Keefektifan penerapannya dilihat dari penerapan substansi hukum, struktural hukum dan budaya hukum. Peningkatan penerbitan KTP Elektronik telah mencapai 96 persen dan dapat disimpulkan efektif.

Faktor-faktor yang mempengaruhi efektivitas penerbitan KTP Elektronik meliputi penerapan substansi hukum, struktur hukum, dan penerapan budaya hukum yang meliputi faktor isi kebijakan, faktor sikap pelaksana kebijakan, faktor pendukung sumber daya, dan faktor kelompok sasaran/wajib KTP Elektronik. Sedangkan faktor hambatan yang mempengaruhi belum tercapainya angka 100 persen, diantaranya pada substansi hukum sanksi yang tercantum jika penduduk wajib KTP Elektronik tidak membawa KTP Elektronik saat berpergian masih sangat rendah yakni hanya $R p$ 50.000 (lima puluh ribu rupiah). Pada penerapan struktur hukum sempat terjadi kekosongan blangko KTP Elektronik dari pemerintah pusat, tidak semua PNS menguasai peralatan pendukung KTP Elektronik. Faktor hambatan dari Budaya Hukum 
yaitu keengganan masyarakat untuk merekam data KTP Elektronik.

\section{E. Saran}

Beberapa saran dalam penelitian ini bagi pemerintah kabupaten/kota meningkatkan sanksi administrasi bagi penduduk wajib KTP Elektronik yang tidak membawa KTP Elektronik selama berpergian melalui Peraturan Daerah tentang Administrasi Kependudukan masingmasing, peningkatan kemampuan Sumber Daya
Manusia di lingkungan Dinas Kependudukan dan Pencatatan Sipil terutama dalam pengoperasian peralatan pendukung KTP Elektronik, masyarakat lebih patuh pada aturan perundang-undangan, tanpa harus dilakukan upaya jemput bola oleh aparatur pelaksana atau sistem door to door, dan meningkatkan keberanian dalam melaporkan pelayanan Adminsitrasi Kependudukan jika terjadi penyimpangan oleh aparatur pelaksana agar tercipta sistem yang lebih baik dalam melaksanakan pelayanan publik.

\section{Daftar Pustaka}

Faturochman, dkk. 2004. Dinamika Kependudukan dan Kebijakan. Pusat Studi Kependudukan dan Kebijakan UGM.

GG. Howard dan RS Summers. 1965. Law : Its Nature and Limits. Prentice Hall : New J ersey

J ohny Ibrahim. 2006. Teori dan Metodologi Penelitian Hukum. Malang : Banyumedia Publishing.

Kansil, C.S.T. 2002. Pemerintah Daerah di Indonesia. Jakarta : Sinar Grafika.

Lawrence M. Friedman. 1984. American Law: An invalueable guide to the many faces of the law, and how it affects our daily lives. New York: W.W. Norton \& Company.

Peter Mahmud Marzuki. 2014. Penelitian Hukum di Indonesia. J akarta : Rajawali Pers.

S etiono, Pemahaman terhadap Metode Penelitian Hukum, (Diktad). 2002.S urakarta: Program Studi IImu Hukum Pascasarjana.

Soerjono Soekanto. 1985. Efektivikasi Hukum dan Peranan Sanksi. Bandung : Remadja Karya.

Soerjono Soekanto. 2002. Faktor-Faktor Yang Mempengaruhi Penegakan Hukum. Jakarta : Raja Grafindo Persada.

Sutrisno Hadi. 1989. Metodologi Penelitian Hukum. Surakarta : UNS Press.

Syaukani H.R. 2007. Peningkatan Kinerja Eksekutif dan Implementasi Otonomi Daerah, dalam Syamsuddin Haris, Desentralisasi dan O tonomi Daerah. J akarta : LIPI P ress Data Kependudukan.

Undang-Undang Nomor 24 Tahun 2013 tentang Administrasi Kependudukan

Undang-Undang Nomor 23 Tahun 2006 tentang Administrasi Kependudukan

SuratE daran Menteri Dalam Negeri Nomor 417/1768/SJ Tentang Percepatan Penerbitan KTP Elektronik Dan Akta Kelahiran

Undang-Undang Nomor 23 tahun 2014 Perubahan Atas Undang-Undang Nomor 32 tahun 2004 tentang Pemerintah Daerah

Badan PusatS tatistik. J umlah dan Distribusi Penduduk. Diakses http://sp2010.bps.go.id/, diakses tanggal 19 Desember 2016.

Deni Setiawan. (1 September 2016). "DATA TERKINI, J umlah Penduduk Indonesia 257,9 J uta, yang Wajib KTP 182,5 J uta". diakses dari http://jateng.tribunnews.com/2016/09/01/data-terkini-jumlahpenduduk-indonesia-2579-juta-yang-wajib-ktp-1825-juta. Diakses pada tanggal 18 Desember 2016

“Mendagri Puji Risma yang Perintahkan Anak Buah Door to Door Layani e-KTP (31 Desember 2016). Diakses dari http://www.kemendagri.go.id/news/2016/08/31/mendagri-puji-risma-yang-perintahkananak-buah-door-to-door-layani-e-ktp. Diakses tanggal 18 Desember 2016. 
"Perekaman KTP el di Tenggarong Car Free Day". (7 November 2016). Diakses dari http://www. kemendagri.go.id/news/2016/11/07/perekaman-ktp-el-di-tenggarong-car-free-day. Diakses pada tanggal 20 Desember 2016

"Blangko E-KTP Gagal Lelang". (16 November 2016). Diakses dari http://www.beritasatu.com/ hukum/399481-blangko-ektp-gagal-lelang.html. Diakses pada tanggal 20 Desember 2016

Muhammad Hadiyan. (6 O ktober 2016). "R ibuan S urat Pengganti KTP EI Diterbitkan sejak B langko Habis". Diakses dari http://www.radarpekalongan.com/54596/ribuan-surat-pengganti-ktp-el-diterbitkansejak-blangko-habis/. Diakses pada tanggal 19 Desember 2016

"Dinas Dukcapil GunungKidul Door to Door e-KTP Samnpai ke Tempat Tidur".

(28 September 2016). Diakses dari http://www.kemendagri.go.id/news/2016/09/28/dinas-dukcapil-gunungkidul-door-to-door-e-ktp-sampai-ke-tempat-tidur/. Diakses pada tanggal 17 Desember 2016

\section{J urnal}

Michael Howlett. 1998. "Policy Subsystem Configurations and Policy Change: Operationalizing the PostpositivistAnalysis of the Politics of the Polycy Process". Policy Studies J ournal. Vol. 26, No. 3.

Thomas Biekland. 1998. "Law, Polycy Making, and the Policy Proces: Closing the Gaps". Policy Studies J ournal, Vol. 26, No. 2. 